\title{
EMPOWERING RURAL YOUTH FOR LIVELIHOOD SECURITY IN NON FARM ACTIVITIES NASREEN BANU
}

Principal Scientist, AICRP-HD All India Coordinated Research Project-Human Development, PGRC, PJTSAU

(Professor Jayashankar Telangana State Agricultural University), Rajendranagar, Hyderabad, India

ABSTRACT
Present study was taken up to address the problems of rural youth in the adopted villages of Moinabad mandal,
RR district, Hyderabad. 70 youth formed the sample for the present study. Checklists developed by the unit (AICRP-
Child Development) were used to find out the problems \& training needs. Based on the training needs, capacity building
programmes were organized to impart skills and to bring them back in to the mainstream of education. Besides this, life
skills training programmes were also conducted recommendations were generated.
KEYWORDS: Empowerment; Livelihood Security; Skill Development

Received: Jul 13, 2017; Accepted: Jul 28, 2017; Published: Aug 01, 2017; Paper Id.: IJESRAUG201712

\section{INTRODUCTION \&BACKGROUND}

Youth Empowerment is an agenda of immense discussions and contemplation worldwide, which has been on the top of lists of most government plans, programs and policies. Empowerment and capacity building provides young people an avenue, to gain practical information and learning for their improved livelihoods.

India can become a developed nation, only if every youth contributes to the best of his or her capacity and ability. Optimum utilisation of the talents of our youth will make India a super power, a developed country by 2020 .

We need to empower our youth, which can only be done through quality education, so that, they will one day become successful leaders in life. 'Empowering youth is the need of hour, as $27.5 \%$ of the population comprise of the age group of 15-29 years, contributing about 34\% of India's Gross National Income (GNI).

Youth empowerment is an attitudinal, structural, and cultural process, whereby, young people gain the ability, authority, and agency to make decisions and implement change in their own lives and the lives of other people, including youth and adults. The World Bank's publication Empowerment and Poverty: A Sourcebook views Empowerment broadly as increasing poor people's freedom of choice and action to shape their own lives. It implies control over resources and decisions (Narayan 2005).

\section{Note: The present study is supported by ICAR under XII plan period}

Rural India today, is undergoing a rapid transformation. Even as agriculture continues to be a major source of livelihood for the rural population, the younger generation is eager to branch out in new directions and is increasingly looking towards alternative sources of livelihood. Rural youth are more focused on getting a good education and trying to obtain jobs that will enable them to become a part of India's growth story in the industrial 
and service sectors.

\section{Research Facts}

- Many youth lack adequate and appropriate education and training (Middletonetal, (1993): Appropriate and useful education is vital, in order for youth to improve their ability to find good jobs and lead responsible and productive lives. But for a number of political, economic and cultural reasons, not all children and youth have schooling or training. This is particularly the case for rural youth in developing countries. An estimated 40 percent of all children in rural areas either do not finish primary school or complete it later than formally expected.

- Youth are the present and the future of humanity, as well as of nations. A well educated and trained population gives a country enormous potential for economic and social development. Youth are also a growing client base. The numbers and potential impact of youth means that, they are a vital part of any sustainable development strategy. It is important that youth are both viewed as an investment opportunity and are treated as partners in the development process (Lakin, M. and Gasperini, L, 2003).

- Young people in rural areas are the future of agriculture and other rural industries, but often lack the guidance and support necessary to fully contribute to the development of their communities, thereby fuelling the vicious cycle of rural underdevelopment and poverty. Acknowledging and addressing their needs and aspirations is vital for local and national growth.

\section{Rationale}

- Nearly half of all people in the world today are under the age of 25. Effectively addressing the special needs of these youth is a critical challenge for the future. Youth, individuals between the ages of 15 and 24, make up over one-sixth of the world's population, but are seldom recognized as a distinct group for the important role they will play in shaping the future.

- More than any other group, today's young women and men will impact how people in rich and poor countries live in the 21st century. Unfortunately, hundreds of millions of youth—especially young women—lack education, skills and job training, employment opportunities, and health services effectively limiting their futures at a very early age.

- Rural India today is undergoing a rapid transformation. Even as agriculture continues to be a major source of livelihoods for the rural population, the younger generation is looking at alternative sources of livelihoods.

- India is among the 'young' countries in the world, with the proportion of the work force in the age group of 15-45 years, increasing steadily. However, presently only $2 \%$ of the total workforce in India has undergone vocational skill training.

Hence, the present project has been taken up on an experimental basis, as well trained, informed \& educated Youth in vocational skills will be able to sustain in nonfarm sector

\section{Operational Definition}

\section{Youth}

The current generation of youth, as defined by the United Nations, aged between 15 to 24 years is the largest in 
history. As of 2012 , the youth make up for 1.8 billion or $18 \%$ of total world population. Ninety percent (90\%) of these young people live in developing countries, comprising as much as $20 \%$ of their countries' total population.

\section{Life Skills}

Life skills have been defined by WHO (1993) as "the abilities for adaptive and positive behavior that enable individuals to deal effectively with the demands and challenges of everyday life". 'Adaptive' means that a person is flexible in approach and is able to adjust in different circumstances. 'Positive behavior' implies that a person is forward looking even in difficult situations.

\section{Life Skills Index}

It is the basic skills required for sustainable agricultural practices as ranked by the experts (from Agriculture, Horticulture, extension, Govt dept \& NGOs working for farming community). It includes 3 major skills: Cognitive skills, Management skills and Interpersonal skills. Cognitive skill were given rank I, followed by Management skills (Rank II) and Interpersonal skills (III), by the experts (36).

\section{Cognitive Skills Include}

Critical thinking, Creative thinking, Decision making and Problem solving

\section{Inter Personal Relationship Skills Include: Communication Skills, Empathy \\ Coping \& Management Skills}

Refers to the ability to recognize, understand and manage one's own emotions as well as others; ability recognize the source of stress and manage it in a constructive way and ability to manage resources and cope with difficult situations.

\section{General Objective of the study}

Empowering Rural youth through Vocational skill development for Livelihood security in Non-Farm activities

\section{Specific Objectives}

- To Characterize the Youth engaged in Non Farm Activities

- $\quad$ To find the life skill levels of the selected sample

- To find out the Constraints of Rural Youth's Involvement in Agriculture

- To find out the Factors influencing Occupational choices as perceived by the youth

- To find out the Awareness levels of the selected sample about Vocational courses

- To find out the Training needs of Youth (men \& women) in Non Farm based vocations

\section{Research Strategy Adopted}

In order to achieve the framed objectives, Capacity building programmes were organized based on training needs, Life skill education programmes, and Awareness cum Interactive sessions were conducted to appraise the youth about the different kinds of educational programmes, in order to bring them back to the mainstream of education, and to widen their employment opportunities. 


\section{Research Methodology}

Sample was identified from the adopted villages (5) of Moinabad mandal, RR District, Hyderabad (AP), through field survey and focused group interviews with the Youth leaders, Adarsharhytu, Book keeper, Ration card dealer, karobar, Village sarpanch \& other active farmers in the village. There were 1255 youth in the age group of $16-25 \mathrm{yrs}$ in the selected villages (5) of Moinabad mandal, RR District.

\section{Criteria for Selecting the Sample}

- Youth, in the age group of $16-25 \mathrm{yrs}$

- Youth, who discontinued studies and involved in nonfarm activities

Out of the total of 1255 youth identified from the 5 adopted villages, 70 samples were selected for research purpose. Youth (both boys \& girls), who were willing to be part of the project formed the sample.

\section{Research Tools}

- Interview schedule was developed and used to collect the baseline data about the selected subjects.

- Life Skill Index developed by AICRP-CD unit, Hyderabad, was used to find out the Life skills levels of the selected sample.

- Open ended checklist developed by AICRP-CD, Hyd unit, to find out the Constraints of Rural Youth's Involvement in Agriculture; Factors influencing Occupational choices as perceived by the youth and Awareness levels of the selected sample about open school system, \& Vocational based courses

- Open ended checklist developed by AICRP-CD, Hyd unit, was to find out the Training needs of the youth in Nonfarm sector

\section{Pre Assessment Results on Selected Parameters/ Variables}

\section{Characterization of Youth Engaged in Nonfarm Activities}

Out of 1255 sample,

- $728(58 \%)$ were boys \& 527 (42\%) were girls.

- $467(37 \%)$ were in the age group of 16- $19 \mathrm{yrs} ; 400(32 \%)$ were in the age group of 19-22 yrs; and $388(31 \%)$ were in the age group of $22-25 \mathrm{yrs}$;

- $\quad 462(37 \%)$ completed SSC; and $208(16 \%)$ discontinued studies after $10^{\text {th }}$ class

- $264(21 \%)$ passed Inter and 200 (16\%)failed Inter / discontinued

- $121(10 \%)$ studying degree college

- $1012(81 \%)$ were engaged in Agriculture

- $28(2 \%)$ were engaged in Sheep rearing

- $93(7 \%)$ were involved in nonfarm activities 
- $122(10 \%)$ were engaged in domestic work.

\section{Life Skills of the Selected Sample}

Life skills have been defined by WHO (1997) as "the abilities for adaptive and positive behavior that enable individuals to deal effectively with the demands and challenges of everyday life". 'Adaptive' means that a person is flexible in approach and is able to adjust in different circumstances. 'Positive behavior' implies that a person is forward looking even in difficult situations.

\section{Life Skill Screening Tools}

For the present study, tools developed by the 9 SAUs under XII plan were used to measure the life skills of the youth. Each life skill has 10 - 25statements. Mostly situation based statements were provided for the sample to respond. Each statement has to be rated as Strongly agree (5), Agree (4), Undecided (3), Disagree (2) and strongly disagree (1), on a 5 point scale. The scores were further grouped in to Low, Average \& High

Table 1: Impact of Life Skill Training on Youth Who Discontinued their Studies N=70

\begin{tabular}{|l|l|c|c|}
\hline \multirow{2}{*}{ Skills } & \multirow{2}{*}{ Categories } & Pre Scores & Post Scores \\
\cline { 2 - 4 } & & No \& \% & No \& \% \\
\hline \multirow{2}{*}{ 1. Cognitive skills } & Low & $45(64 \%)$ & $30(43 \%)$ \\
\cline { 2 - 4 } & Average & $20(29 \%)$ & $33(47 \%)$ \\
\hline \multirow{3}{*}{$\begin{array}{l}\text { 2.Inter Personal } \\
\text { Relationship Skills }\end{array}$} & High & $5(7 \%)$ & $7(10 \%)$ \\
\hline \multirow{3}{*}{\begin{tabular}{l} 
3. Management Skills \\
\cline { 2 - 4 }
\end{tabular}} & Low & $25(36 \%)$ & $18(26 \%)$ \\
\cline { 2 - 4 } & Average & $30(43 \%)$ & $27(38 \%)$ \\
\cline { 2 - 4 } & High & $15(21 \%)$ & $25(36 \%)$ \\
\cline { 2 - 4 } & Low & $30(43 \%)$ & $23(33 \%)$ \\
\cline { 2 - 4 } & High & $28(40 \%)$ & $25(36 \%)$ \\
\hline
\end{tabular}

The above table presents the Life skills of rural youth. Based on the scores, Life skill education programmes (10) were organised for the youth (boys \& girls) separately). Some of the Effective training methodologies used for enhancing Life skills were: Group discussions; Role plays; Brain storming; Group activities; Games \& simulations; Situation analysis; Case studies; Open ended stories and Responding to life situations. Post scores showed significant improvement.

With Regard to Cognitive Skills, 64\% (45) of the sample who obtained low scores during pretest, 43\% (30) of the sample obtained low score, as $47 \%$ (33) of the sample moved on to average and 10\% (7) obtained higher scores during posttest, reflecting the impact of Life skill training programme. This means that the ability to analyze information and experiences in an objective manner has changed for the better; the sample were able to make effective decisions and solve problems effectively.

With Regard to Inter Personal Relationship Skills, $43 \%$ (30) of the sample who obtained average scores during pretest, $38 \%$ (27) of the sample obtained average score, as $36 \%$ (25) moved on to higher scores during posttest, reflecting the impact of Life skill training programme. This means that the ability to express, both verbally and non-verbally, in ways that are appropriate to the situations has improved; sample was able to relate in positive ways with people; and understand the feelings of others.

With Regard to Management Skills, 43\% (30) of the sample who obtained low scores during pretest, 33\% (23) of the sample obtained low score, as 36\% (25) obtained average score and 31\% (22) obtained higher scores, reflecting the 
impact of Life skill training programme. This means that the sample was able to manage their emotions \& stress quiet effectively and also manage their resources.

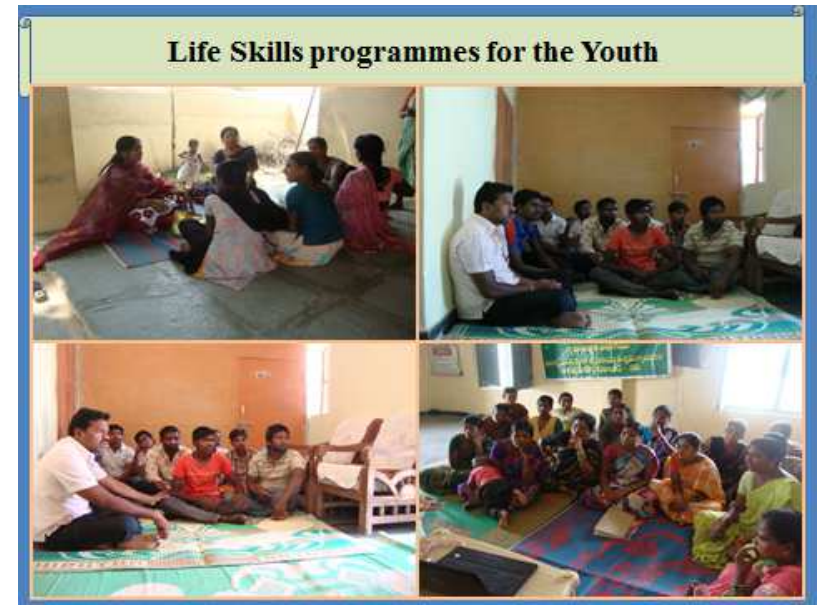

Figure 1

CONSTRAINTS OF RURAL YOUTH'S INVOLVEMENT IN AGRICULTURE (N= 70)

Table 2

\begin{tabular}{|c|c|c|c|}
\hline S. No & Constraints & No \& \% & Ranking \\
\hline 1 & Inadequate credit facility & $43(61 \%)$ & 5 \\
\hline 2 & Poor returns to investment & $61(87 \%)$ & 1 \\
\hline 3 & $\begin{array}{l}\text { Not perceived as a viable } \\
\text { business }\end{array}$ & $58(83 \%)$ & 2 \\
\hline 4 & No ready market & $55(78 \%)$ & 3 \\
\hline 5 & It is Energy-Sapping & $55(78 \%)$ & 3 \\
\hline 6 & Farmers are not respected & $50(71 \%)$ & 4 \\
\hline 7 & Not an Attractive Career Path & $58(83 \%)$ & 2 \\
\hline 8 & Insufficient land & $38(54 \%)$ & 5 \\
\hline
\end{tabular}

The above table presents the Constraints of Rural Youth's Involvement in Agriculture: some of the reasons expressed were: Poor returns to investment (87\%); Not perceived as a viable business $(83 \%) \&$ Not an attractive career path $(83 \%)$; No ready market (78\%) \&It is energy-sapping (78\%); Farmers are not respected (71\%); Inadequate credit facility (61\%) and Insufficient land: 38 (54\%).

\section{FACTORS INFLUENCING OCCUPATIONAL CHOICES AS PERCEIVED BY THE YOUTH}

Table 3

\begin{tabular}{|l|c|c|}
\hline \multicolumn{1}{|c|}{ Factors Influencing Occupational Choice } & No \& \% & Ranking \\
\hline Job availability & $46(66 \%)$ & $\mathbf{1}$ \\
\hline Employment / job security & $46(66 \%)$ & $\mathbf{1}$ \\
\hline Career flexibility & $46(66 \%)$ & $\mathbf{1}$ \\
\hline Vocational guidance & $40(57 \%)$ & $\mathbf{3}$ \\
\hline Transport facility / accessibility & $20(28 \%)$ & $\mathbf{4}$ \\
\hline Information about Career choices in the market & $42(60 \%)$ & $\mathbf{2}$ \\
\hline $\begin{array}{l}\text { Information about centers / firms which offer } \\
\text { vocational based skill training programmes }\end{array}$ & $42(60 \%)$ & $\mathbf{2}$ \\
\hline
\end{tabular}


- The above table presents Factors influencing Occupational choices as perceived by the youth: Job availability, Employment / job security and Career flexibility (66\%); Information about Career choices in the market \&Information about centres / firms which offer vocational based skill training programmes (60\%); Vocational guidance (57\%) \&Transport facility / accessibility (28\%).

\section{AWARENESS ABOUT VOCATIONAL COURSES N=70}

None of them were aware of job oriented vocational courses; short term vocational certificate courses; Open school system of education

Table 4: Reasons for Not Wanting to Do Vocational Education Courses

\begin{tabular}{|l|l|}
\hline \multicolumn{1}{|c|}{ Reasons } & No \& \% \\
\hline Do not have much choice to select from vocational courses & $40(57 \%)$ \\
\hline Don't know about a good vocational education course & $38(54 \%)$ \\
\hline Family discourages vocational education & $32(46 \%)$ \\
\hline Vocational courses are very costly & $46(66 \%)$ \\
\hline Vocational education is not prestigious & $42(60 \%)$ \\
\hline Not sure whether job placements are available & $40(57 \%)$ \\
\hline
\end{tabular}

The above table presents some of the reasons for not opting for vocational education courses were: Vocational courses are very costly (66\%); Vocational education is not prestigious (60\%); Not sure whether job placements are available\& Do not have much choice to select from vocational courses (57\%); Don't know about a good vocational education course (54\%) and Family discourages vocational education (46\%).

\section{Reasons Why Rural Youth Education Levels Are Below Those of Urban Youth}

- The School curriculum is not designed for the situation, future needs or interests of rural youth. Many drop out because what they are taught seems irrelevant to their needs.

- Many rural families cannot afford the opportunity costs of keeping youth at school when their labour is needed; so many children only attend school in the off-peak agricultural season.

Based on the findings, Awareness cum Interactive sessions were organized (6) for the Youth to appraise them about the different kinds of educational programmes (short term vocational courses, certificate courses, open school programmes, job oriented vocational courses, skill based training course etc) being offered by APOSS, and State Institute for Vocational Education to enable the rural youth to enhance their educational status.

\section{Input / Action Plan}

Awareness cum Interactive sessions were organized (6) for the Youth to appraise them about the different kinds of educational programmes (short term vocational courses, certificate courses, open school programmes, job oriented vocational courses, skill based training course etc) being offered by APOSS, and State Institute for Vocational Education to enable the rural youth to enhance their educational status. 


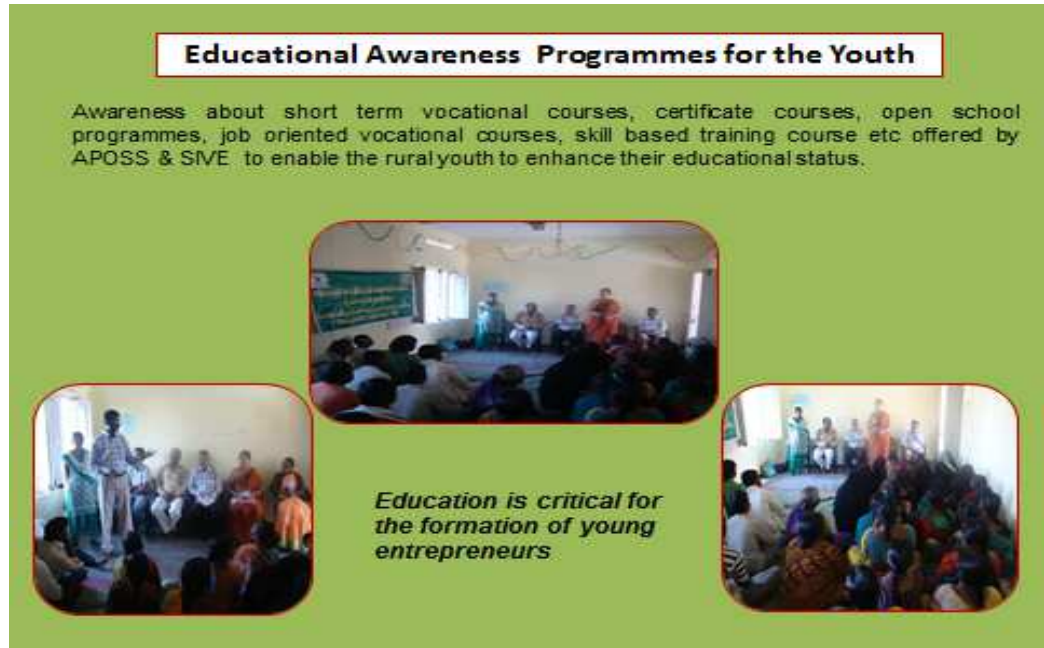

Figure 2

\section{Need for Organizing Educational Awareness Programmes}

- Rural areas lack opportunities for educated youth to employ their skills productively, thus encouraging outmigration that results in a 'rural youth drain'.

- Every year rural areas lose a vital part of its workforce as young people migrate to urban areas in search of economic opportunities.

- Youth in rural areas of many developing countries are involved in a range of household-based and farm and offfarm activities, where the main problem they face is that of under -employment as these activities often have low rates of return.

- Poverty, lack of voice, and of decent work opportunities may contribute to a sense of hopelessness that can discourage young people.

- Young rural women are doubly disadvantaged as a result of traditional gender-based stereotypes and gender-based division of labour especially persistent in rural areas, which limit, in particular, their access to education and decent, remunerative work.

\section{Impact / Outcome}

Few of the sample (7) joined open schools to continue their studies; and few (11) joined Intermediate vocational courses. Few of the sample(6) underwent computer maintenance skill training at Dr. Reddys foundation and 3 attended 45 days skill training programme in Electrician course free of cost offered by APBIRED.

\section{TRAINING NEEDS OF THE RURAL YOUTH}

Table 5: Training Needs of Youth in Non Farm Based Vocations (N=32)

\begin{tabular}{|l|c|c|}
\hline \multicolumn{1}{|c|}{ Specific Area } & $\%$ & Ranking \\
\hline 1. Computer maintenance \& operation work & $62 \%$ & 1 \\
\hline 2. Electrical installation \& maintenance work & $62 \%$ & 1 \\
\hline 3. Graphic art / Multimedia & $40 \%$ & 5 \\
\hline 4. Electrical appliance repairs & $60 \%$ & 2 \\
\hline
\end{tabular}




\begin{tabular}{|l|l|l|}
\hline \multicolumn{3}{|c|}{ Table 5: Contd., } \\
\hline 5. Plumbing \& pipe fitting & $52 \%$ & 3 \\
\hline 6. Motor cycle repairs and servicing & $60 \%$ & 2 \\
\hline 7. Welding work & $43 \%$ & 4 \\
\hline
\end{tabular}

\section{Non Farm Based Vocations}

In this area, in the order of ranking, youth showed first preference (89\%) for both Computer maintenance \& operation work and Electrical installation \& maintenance work; $2^{\text {nd }}$ preference $(87 \%)$ for both Electrical appliance repairs $\&$ Motor cycle repairs and servicing; $3^{\text {rd }}$ preference $(75 \%)$ for Plumbing \& pipe fitting; $4^{\text {th }}$ preference $(62 \%)$ for Welding workand $5^{\text {th }}$ preference $(57 \%)$ for Graphic art/ Multimedia.

The above results indicate relatively high percentage of youth (young farmers) opting for both Computer maintenance \& operation work (89\%) and Electrical installation \& maintenance work. The high percentage observed with these two vocations can be attributed to the obvious fact that computer operations cover all facets of life and preference for Electrical installation \& maintenance work could be attributed to high demand for technological development.

The next preference was observed for both Electrical appliance repairs (87\%) and Motor cycle repairs \& servicing. This could be attributed to the fact that both these vocations have high demand in urban areas. The next preference in a sequence was observed for Plumbing \& pipe fitting (75\%); for Welding work (62\%) and for Graphic art/ Multimedia (57\%).

Table 6: Training Needs of Adolescent Girls in Non Farm Based Vocations $(\mathrm{N}=38)$

\begin{tabular}{|l|c|c|}
\hline \multicolumn{1}{|c|}{ Specific Area } & \% & Ranking \\
\hline 1. Bakery products \& Confectionary & $50 \%$ & 2 \\
\hline 2. Garment construction \& designing & $62 \%$ & 1 \\
\hline 3. Food Preservation \& Processing & $43 \%$ & 3 \\
\hline 4. Masala powders & $43 \%$ & 3 \\
\hline 5. Desktop publications \& printing & $40 \%$ & 4 \\
\hline 2. Beautician course & $33 \%$ & 5 \\
\hline 3. Tailoring and stitching & $62 \%$ & 1 \\
\hline 4. Physiotherapy & $26 \%$ & 6 \\
\hline
\end{tabular}

In the order of ranking, Adolescent girls showed first preference (62\%) for both Garment construction \& designing and Tailoring and stitching; $2^{\text {nd }}$ preference $(50 \%)$ for Bakery products \& Confectionary; $3^{\text {rd }}$ preference $(43 \%)$ for both Food Preservation \& Processing and Masala powders; $4^{\text {th }}$ preference for Desktop publications $\&$ printing $(40 \%) ; 5^{\text {th }}$ preference $(33 \%)$ for Beautician course and $6^{\text {th }}$ preference $(26 \%)$ for Physiotherapy .

\section{Other Action Plans Generated}

- Grouping of the youth was done based on the training needs of the Youth

- Stakeholders (Govt, PVT, NGOs) were identified based on the training needs of the Youth

\section{Impact / Outcome}

- Few of the samples (6) underwent computer maintenance skill training at Dr. Reddys foundation and 3 attended 45 days skill training programme in Electrician course free of cost offered by APBIRED. 
Table 7: Stakeholders Who Were Involved In Conducting Capacity Building Programmes for the Rural Youth for Livelihood Security in Nonfarm Sector

\begin{tabular}{|c|c|c|}
\hline S. No & Organization/Institute & Focus of the Programmes \\
\hline 1 & $\begin{array}{l}\text { Khadi Gramodyog } \\
\text { MahaVidyalaya, } \\
\text { Rajendranagar }\end{array}$ & $\begin{array}{l}\text { Empowering Rural Families through Skill training } \\
\text { programmes } \\
\text { - Short term \& Long term (with \& without stipend); } \\
\text { - Residential \& Off campus programmes }\end{array}$ \\
\hline 2 & $\begin{array}{l}\text { State Intermediate Board of } \\
\text { Vocational Education } \\
\text { (SIVE), Nampally }\end{array}$ & $\begin{array}{l}\text { Demand \& Job based Vocational educational } \\
\text { Courses; Certificate courses }\end{array}$ \\
\hline 3 & $\begin{array}{l}\text { AP Open School Society, } \\
\text { opposite Fatemaidan, Abids }\end{array}$ & $\begin{array}{ll}\text { - } & \text { Mainstreaming children who discontinued } \\
\text { studies } & \\
\text { - } & \text { Programmes to make illiterate population } \\
\text { literate. } & \end{array}$ \\
\hline 4 & $\begin{array}{l}\text { Dr.Reddys Foundation, } \\
\text { Somajiguda }\end{array}$ & $\begin{array}{l}\text { Sustainable Livelihoods for the underprivileged } \\
\text { Rural youth. }\end{array}$ \\
\hline & $\begin{array}{l}\text { Center for Rural } \\
\text { Infrastructure (CRI), NIRD }\end{array}$ & - $\quad$ Sustainable Livelihoods in non farm sectors \\
\hline 5 & $\begin{array}{l}\text { Rural technology Park, } \\
\text { NIRD }\end{array}$ & $\begin{array}{l}\text { Dissemination of affordable technologies } \\
\text { through training programmes to the rural community for } \\
\text { quality life: }\end{array}$ \\
\hline 6 & $\begin{array}{l}\text { Andhra Pradesh Banker's } \\
\text { Rural Entrepreneurship } \\
\text { Development (APBRED) }\end{array}$ & $\begin{array}{l}\text { Entrepreneurial activities for Sustainable } \\
\text { Livelihoods }\end{array}$ \\
\hline 7 & $\begin{array}{l}\text { Andhra Pradesh Rural } \\
\text { livelihood Project (APRLP), }\end{array}$ & $\begin{array}{ll}- & \text { Livelihoods Enhancement } \\
\text { - } & \text { Skilled wage employment } \\
\text { - } & \text { Nurturing self-employed for micro-enterprises }\end{array}$ \\
\hline
\end{tabular}
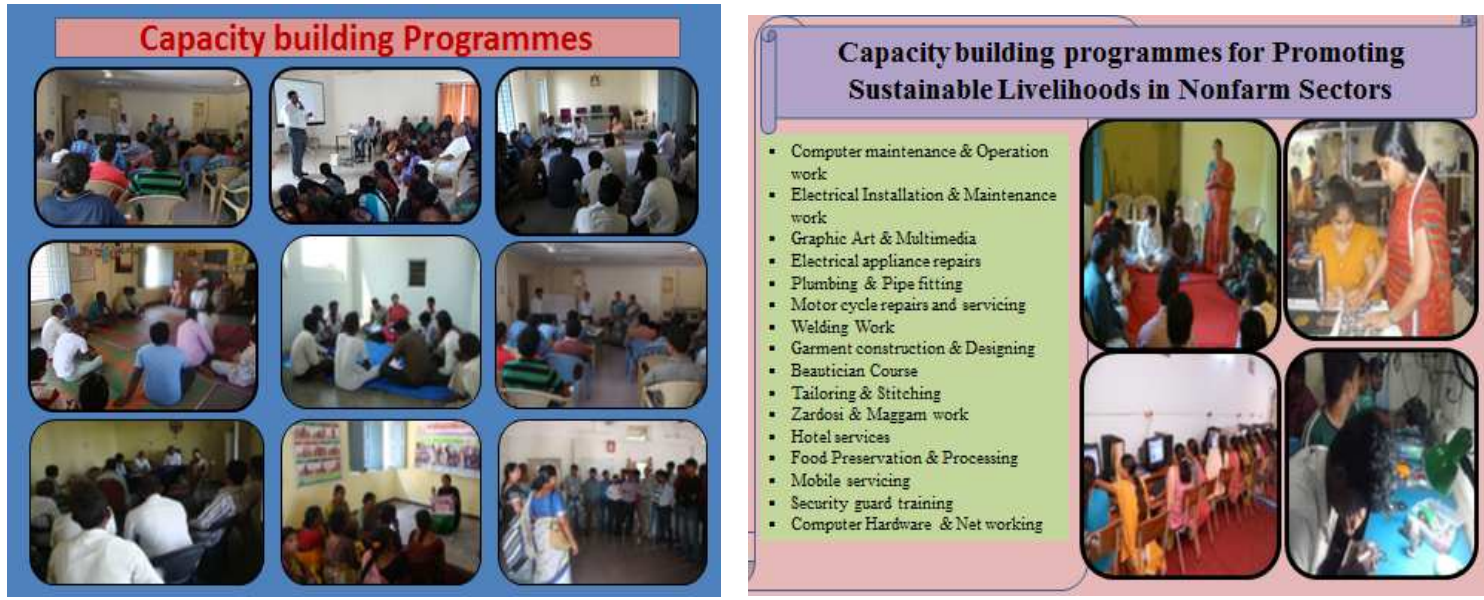

Figure 3

\section{Expected Outcome}

- Youth equipped with coping skills, social competencies will be able to manage challenging situations and utilize existing opportunities, optimally

- Young people empowered with adequate Knowledge and skill required for sustainability in Farm \&Non-Farm based enterprise 


\section{Following IEC Material was Developed for the Rural Youth in Support of the Framed Objectives}

- Life Skill educational Training modules (10) in regional language for the key persons (change agents) for the sustenance of the programme.

- Resource book on 'Demand based vocational courses' to widen the employment opportunities of Youth who discontinued studies.

- Developed Training module on 'Home based Viable microenterprises' for the livelihood security of youth
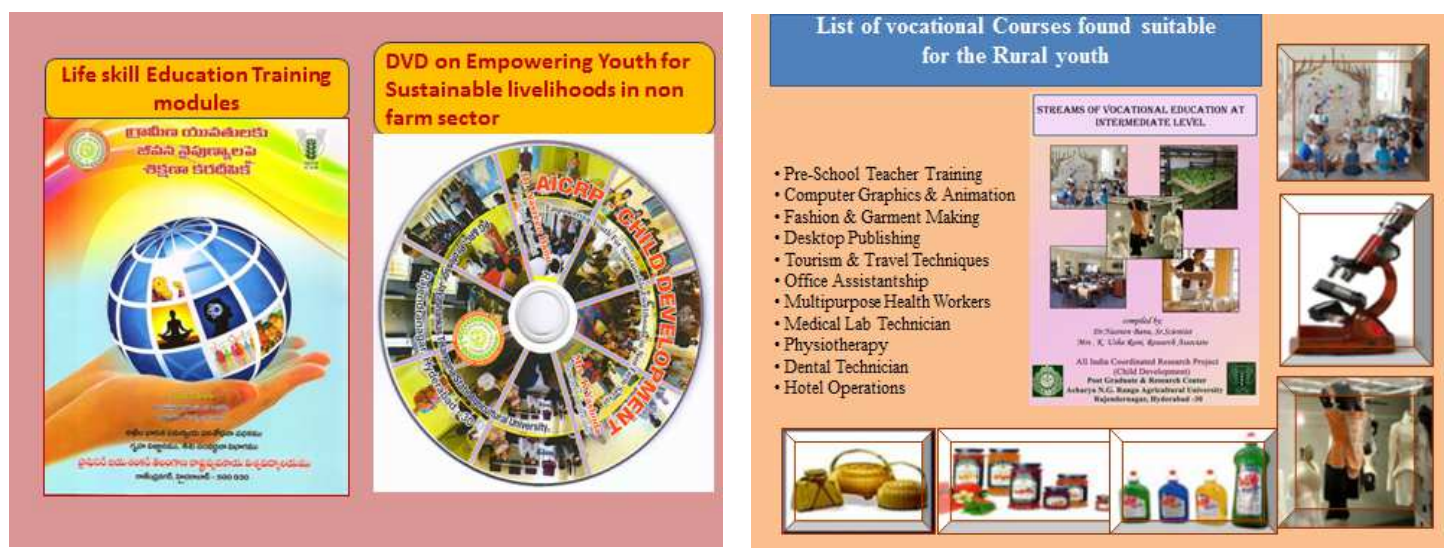

Figure 4

Based on the Findings following Conceptual Models Were Developed for Empowering Youth in Nonfarm Activities
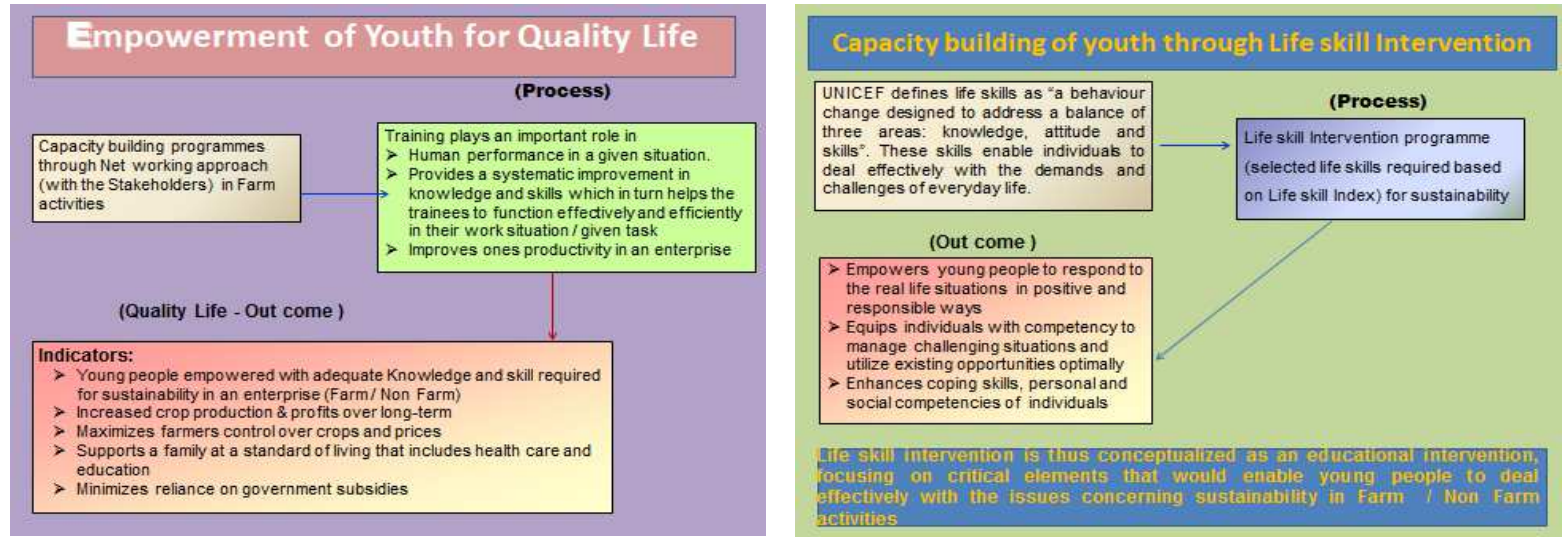

Figure 5

\section{RECOMMENDATIONS FRAMED BASED ON THE RESULTS}

- $\quad$ Training of young women and men should aim both to strengthen their potential in the labour market as well as self-employed entrepreneurs.

- Both formal and informal activities need to be targeted to address their specific opportunities and challenges, and when possible, formalisation should be supported.

- Gender imbalances in access to resources, trainings and other empowering features need to be explicitly addressed and compensated. 
- Ensure that rural education and training provide rural girls and boys with the skills necessary for living and working productively in rural areas.

- Integrate entrepreneurship skills in rural education and training curricula, so as to sensitize young women and men to the possibility of setting up rural enterprises, and give them basic information on what steps to take.

- Provide career guidance to rural youth at an early age to inform them of job prospects in their region, as well as about the technical and personal skills needed for those jobs.

- Support entrepreneurship of young men and women through proper training, access to credit, and other business development services.

- Encourage micro-credit facilities to extend grants and loan services to rural youth. Qualifying recipients should also be given the guidance, as well as freedom, to choose how best to use the funds.

\section{WHY ACTION IS NEEDED}

- Rural people's access to education and training is often limited by financial barriers (e.g. training and transportation costs) and non-financial barriers (e.g. scarce education and training infrastructure, inflexible training schedules).

- Especially for poor rural children and adults, the opportunity costs for education and training may be too high to give up their income-generating activities and unpaid duties that help sustain their families.

- Many rural people do not have basic education. This also hampers their access to technical and vocational training or other skills development. Unequal gender relations and traditional gender roles entail specific difficulties for rural girls and women in accessing education and training.

- Education and training is often of inadequate quality. Teachers and trainers may be unqualified, equipment and technology out-dated, and teaching and training methods ill-suited to rural contexts.

- In many developing countries, training systems tend to operate in isolation from the labour market and employers' needs, so training does not always match skills demand.

\section{CONCLUSIONS}

- India is a young country, with 70 percent of people below the age of 35 years. It is this young population which constitutes for India, a potential demographic dividend, which needs to be properly addressed and harnessed towards positive, constructive and purposeful activities by imparting quality education, skill based training, gaining access to Information and Communication Technology and urgent attention to improving their quality of life.

- Lack of access to formal education and vocational training, unable to access Information and Communication technology, increasing youth unemployment, malnutrition, are the main challenges before the empowerment of youth in the today's century. 


\section{REFERENCES}

1. Bennell, P (IFAD, Rome: 2007). Promoting livelihood opportunities for rural youth, knowledge and skills for development

2. Lakin, M. and Gasperini, L, 2003, "Basic Education in rural areas: status, issues and prospects", in Education for Rural Development: Towards new policy responses, D. Atchaoarena and L. Gasperini (eds), FAO, Rome / UNESCO-IIEP, Paris, pp $112-113$

3. Middleton, J, Ziderman, A. \& Van Adams, A. (1993).Skills for Productivity: Vocational Education and Training in Developing Countries. New York: Oxford University Press.

4. Narayan, Deepa. (2005). Measuring Empowerment: Cross Disciplinary Perspectives. Washington, DC: World Bank.

5. Singh, R. ((2008). 'Education, Skills and Vocational Training and Access to Rural Non-farm Employment', in the Indian Journal of Labour Economics, Vol. 51, No. 4

6. WHO Life skills project (1997), Programme on Mental health, Geneva

7. World Bank (2010). India's Employment Challenge - Creating Jobs, Helping Workers. New Delhi: Oxford University Press 
